Journal of Epidemiology and Public Health (2017), 2(1): 82-92

https://doi.org/10.26911/jepublichealth.2017.02.01.08

\title{
Biopsychosocial Determinants of Quality of Life in the Elderly at Tresna Werdha Social Nursing Home, Yogyakarta
}

\author{
Sobma Swastika'), Setyo Sri Rahardjo²), RB Soemanto3) \\ ${ }^{1)}$ Masters Program in Public Health, Universitas Sebelas Maret \\ 2)Faculty of Medicine, Universitas Sebelas Maret \\ 3)Faculty of Social and Political Science, Universitas Sebelas Maret
}

\begin{abstract}
Background: Aging process is a multidimensional natural process with implicating problem involving various aspects, i.e. biological, psychological, and social aspects. Efforts are needed to prolong life expectancy and to improve the quality of life of the elderly. This study aimed to analyze biopsychosocial determinants of quality of life in the elderly at Tresna Werdha Social Nursing Home, Yogyakarta.

Subjects and Method: This study was analytic observational study with cross-sectional design. It was conducted at Abiyoso and Budi Luhur units, Tresna Werdha Social Nursing Home, Yogyakarta, in April 2017. A sample of 100 elderly were selected for this study by purposive sampling and simple random sampling. The independent variables were health status, level of independence, intellectual function, depression, and social activities. The dependent variable was quality of life. The data were collected by a set of pre-tested questionnaire and analyzed by logistic regression.

Results: Biopsychosocial determinants of quality of life in the elderly included health status (OR= $11.66 ; 95 \% \mathrm{CI}=2.18$ to $62.14 ; \mathrm{p}=0.004)$, level of independence $(\mathrm{OR}=4.12 ; 95 \% \mathrm{CI}=1.08$ to 15.60 ; $\mathrm{p}=0.037)$, intellectual function $(\mathrm{OR}=9.75 ; 95 \% \mathrm{CI}=1.09$ to 87.08; $\mathrm{p}=0.036)$, depression $(\mathrm{OR}=$ $3.38 ; 95 \% \mathrm{CI}=1.01$ to $11.24 ; \mathrm{p}=0.047)$, and social activities $(\mathrm{OR}=6.02 ; 95 \% \mathrm{CI}=1.12$ to $32.25 ; \mathrm{p}=$ 0.047).

Conclusion: Health status, level of independence, intellectual function, depression, and social activities, are biopsychosocial determinants of quality of life in the elderly
\end{abstract}

Keywords: biopsychosocial, determinant, quality of life, elderly

Correspondence:

Sobma Swastika. Masters Program in Public Health, Universitas Sebelas Maret. Jl. Ir. Sutami 36 A, Surakarta, Central Java. Email: sobmaswastika@gmail.com. Mobile: +628113239862.

\section{BACKGROUND}

$\overline{\text { Population aging is one of the crucial issues }}$ faced by many countries in the world. The composition of the elderly population rapidly increases both in developed and developing countries, this is due to a decrease in birth rates, a decrease in mortality, and an increase in life expectancy that changes the overall population structure (Nugroho, 2008).

Life expectancy in the world in 2015 was 70.5 years (with an elderly population of $903,985,056$ people or $12.3 \%$ ), this figure is expected to continue to increase to 77.1 years in 2050 (with an elderly population of $2,090,906,820$ people or $21.5 \%$ ) and to be 83.2 years in 2100 (with an elderly population of $3,173,368,710$ people or $28.3 \%$ ) (UN, 2015). Indonesia is the fourth country with the largest population in the world after China, India and the United States, and as the country with the largest population in Southeast Asia from the 10 countries that are members of ASEAN (Association of Southeast Asian Nations), Indonesia should be a role model for neighboring countries, especially in handling the population, espe- 
cially the elderly population (Central Statistical Agency, 2016).

The implementation of national development aimed at creating a just and prosperous society based on Pancasila and the 1945 Constitution has resulted in better social conditions of the community and increasing life expectancy, so that the number of elderly population is increasing (Central Statitical Agency, 2011).

The number of elderly population in Indonesia in 2015 was $21,120,248$ people or $8.2 \%$, this shows that Indonesia began to fall into the group of old structured countries because the percentage of the elderly continued to exceed $7 \%$. This condition is expected to continue to increase in line with the increasing life expectancy (Ministry of Health, 2016).

Life expectancy in Indonesia in 2015 was 68.6 years (with an elderly population of $21,120,248$ people or $8.2 \%$ ), this figure is expected to continue to increase to $73.9 \mathrm{ye}-$ ars in 2050 (with an elderly population of $61,869,504$ people or $19.2 \%$ ) and become 81.2 years in 2100 (with an elderly population of $90,957,920$ people or $29 \%$ ) (UN, 2015).

The Special Province of Yogyakarta is the province with the highest life expectancy in Indonesia, this figure shows an increasing trend over the past 3 years (Central Statitical Agency, 2016a). Life expectancy in Yogyakarta Special Region in 2013 was 74.45 years. In 2014, it was 74.50 years, and in 2015 it was 74.68 years (Central Statitical Agency Yogyakarta Province, 2016).

The results of the population census in 2010 showed that generally, the number of elderly people in the Special Province of Yogyakarta was 448,223 people or $12.96 \%$ of the total population, with the number of elderly women (249,784 inhabitants) more than the total elderly male population (
198,439 people, and when viewed by age group, the number of elderly people in the Special Province of Yogyakarta is divided into young people (60-69 years) of 230,497 people, advanced middle age (70-79 years) of 155,740 people, and continued old age (80 years and over) of 61,986 people (Central Statitical Agency, 2011).

The aging process in the elderly causes a decline in body function due to various changes that occur, therefore good attention and handling is needed. Attention to the elderly is given by the United Nations by making October 1 as the International Elderly Day contained in UN resolution No. 45/106 dated December 14, 1990 and the Indonesian government followed up on the United Nations resolution by making May 29 the National Elderly Day, expected to commemorate the old days, the government and the public are more concerned about elderly social welfare, because after all the government and the community is responsible for the realization of elderly social welfare (Tamher \& Noorkasiani, 2009).

Efforts to improve elderly social welfare are directed so that older people can still be empowered so that they play a role in development activities by taking into account their function, age, wisdom, expertise, experience, skills, knowledge, and physical conditions, as well as the maintenance of the level of elderly social welfare to extend life expectancy and improve the quality of life for the elderly (Sunaryo et al., 2015).

Biopsychosocial aspects are one of the determinants of health in environmental factors, the environment made by humans can affect health, including in the elderly (Swarjana, 2016). If previously the health model only recognized the health biomedical model that fully focused on the biological aspects, then in 1977, the world began to recognize the health biopsychosocial model 
Journal of Epidemiology and Public Health (2017), 2(1): 82-91

https://doi.org/10.26911/jepublichealth.2017.02.01.08

that focused on the biological, psychological, and social aspects (Murti, 2016).

UWO-HAMS (2007), Molton and Jensen (2010), and Jabin (2013) stated that aging in humans is a multidimensional natural process with various problems in various aspects, namely biological, psychological, and social aspects.

Elderly age can be said as the golden age, because not everyone can reach that age, therefore elderly people also need health efforts that are promotive and preventive so that the elderly can enjoy the golden age and become useful, happy, and prosperous (Maryam et al., 2008).

In order to realize the elderly social welfare, the government must facilitate elderly people, both in the elderly who are potential and those who are not potential and good for the elderly who have a family or those who do not have a family, one of them is through the Tresna Werdha Social Service Center, namely the hall social service that is tasked with providing guidance and service for the elderly in order to live well and be cared for in community life. Yogyakarta Special Region Province has 2 units of Tresna Werdha Social Service Center, namely Abiyoso Unit and Budi Luhur Unit. Based on the preliminary study conducted in January 2017, the results showed that Abiyoso Unit had 13 guest houses with 126 elderly and the Budi Luhur Unit had 9 guesthouses which were occupied by 88 elderly people, and of 214 elderly who attended the Tresna Social Service Center. Each woman has different condition which greatly affect the quality of life of the elderly.

This study aimed to analyze the determinants of biological, psychological, and social factors in the quality of elderly life at Tresna Werdha Social Service Center in Yogyakarta.

\section{SUBJECTS AND METHOD}

\section{Study Design}

This was an observational analytic study with a cross-sectional approach conducted at the Tresna Werdha Yogyakarta Social Service Center, namely at Abiyoso Unit and at Budi Luhur Unit in April 2017.

\section{Population and Samples}

The population of this study were all elderly people living at the Tresna Werdha Social Service Center in Yogyakarta, which was 126 elderly in the Abiyoso Unit and 88 elderly in the Budi Luhur Unit, with a total population of 214 elderly people. A sample of 100 elderly were selected by purposive sampling and simple random sampling methods and by taking into account inclusion and exclusion criteria. Inclusion criteria included elderly living at the Tresna Werdha Social Service Center in Yogyakarta, namely at Abiyoso Unit and in the Budi Luhur Unit, elderly aged $\geq 60$ years, and elderly who were willing to participate as study subjects and signed informed consent, while the criteria exclusion includes elderly who cannot communicate verbally well and elderly who are treated in special care rooms.

\section{Study Variables}

The independent variables were health status, level of independence, intellectual function, depression status, and social activities. The dependent variable was the quality of life of the elderly.

\section{Operational Definition of Variables}

Health status was defined as an elderly health condition currently measured using the Vulnerable Elders Survey questionnaire. The categorical measurement scale was with parameter $0=\operatorname{bad}$ and $1=$ good.

The level of independence was defined as the ability of the elderly to carry out daily activities related to physical functions measured using the Katz Index of Activities of Daily Living questionnaire. The categorical 
measurement scale was with parameter $\mathrm{o}=$ dependent and 1 = independent.

Intellectual function was defined as an assessment of orientation, knowledge, short-term memory, long-term memory, and basic math skills in the elderly measured by using the Short Portable Mental Status Questionnaire. The categorical measurement scale was parameter $0=$ decreases and $1=$ intact.

Depression status was defined as a prolonged condition of disruption of mood in the elderly which generally arises due to loss of hope or feelings of helplessness measured using the Geriatric Depression Scale questionnaire. A categorical measurement scale was done with parameters $\mathrm{O}=$ depression and $1=$ not depression.

Social activities were defined as elderly participation in social activities organized by the Tresna Werdha Social Service Center of the Special Province of Yogyakarta. The categorical measurement scale was with parameter $\mathrm{o}=$ not participating and $1=$ participating.

\section{Table 1. Sociodemographic characteristics of study subjects}

\begin{tabular}{|c|c|c|c|}
\hline & Variables & $\mathbf{N}$ & $\%$ \\
\hline Age & 60-74 years & 54 & 54 \\
\hline & $75-90$ years & 42 & 42 \\
\hline & $\geq 90$ years & 4 & 4 \\
\hline Gender & Male & 39 & 39 \\
\hline & Female & 61 & 61 \\
\hline Religion & Moslem & 74 & 74 \\
\hline & Catholic & 13 & 13 \\
\hline & Christian & 13 & 13 \\
\hline Marital Status & Single & 17 & 17 \\
\hline & Married & 47 & 47 \\
\hline & Divorced & 10 & 10 \\
\hline & Widow/widower (because of death) & 26 & 26 \\
\hline Education & Low & 84 & 84 \\
\hline & High & 16 & 16 \\
\hline
\end{tabular}

The characteristics of study variables are in the form of health status, level of independence, intellectual function, depression status, social activity, and quality of life are shown in Table 2.
Elderly quality of life was defined as the perception of the elderly about their ability to carry out daily activities in accordance with their health conditions as measured by the WHOQOL-BREF (World Health Organization Quality of Life-BREF) questionnaire. The categorical measurement scale was with parameter $\mathrm{O}=\operatorname{bad}$ and $1=$ good.

\section{Data Analysis}

The analytical model used was multiple logistic regression using the SPSS program (Statistical Package for Social Science) version 22.

\section{RESULTS}

\section{A. Univariate Analysis}

Table 1 shows that the majority of the 100 study subjects were 60-74 years consisting of 54 people (54\%), the female ones were 61 people (61\%), Muslims were 74 people (74\%), the married ones were 47 people (47\%), and those with low education were 84 people (84\%) 
Journal of Epidemiology and Public Health (2017), 2(1): 82-91

https://doi.org/10.26911/jepublichealth.2017.02.01.08

people (65\%), had an independent level of independence of 54 people (54\%), experienced depression consisting of 62 people
(62\%), participated in social activities of 67 people (67\%), and had a poor quality of life of 76 people $(76 \%)$.

Table 2. Sample Characteristics about the Main Variables of the Study

\begin{tabular}{llll}
\hline \multicolumn{1}{c}{ Variable } & & n & \% \\
\hline Health Status & Poor & 35 & 35 \\
Level of Independence & Good & 65 & 65 \\
& Not Independent & 46 & 46 \\
Intellectual Function & Independent & 54 & 54 \\
& Decrease & 24 & 24 \\
Depression Status & Stable & 76 & 76 \\
& Depressed & 62 & 62 \\
Social Activities & Not Depressed & 38 & 38 \\
\multirow{2}{*}{ Elderly Quality of Life } & Not Participating & 33 & 33 \\
& Participating & 67 & 67 \\
& Poor & 76 & 76 \\
\hline
\end{tabular}

\section{B. Bivariate Analysis}

The results of Chi Square test in analyzing the effect of each independent variable (health status, level of independence, intellectual function, depression status, and social activity) on the dependent variable (elderly quality of life) can be seen in Table 3. Elderly who have good health status $(\mathrm{OR}=8.44$;

Table 3. The Results of Bivariate Analysis with Chi Square Test on the Biopsychosocial Determinant of the Quality of Life Among Elderly at Tresna Werdha Social Nursing Home, Yogyakarta

\begin{tabular}{|c|c|c|c|c|c|c|c|c|}
\hline \multirow{3}{*}{ Variable } & \multicolumn{4}{|c|}{ Quality of Life } & \multirow{2}{*}{\multicolumn{2}{|c|}{ Total }} & \multirow{3}{*}{ OR } & \multirow{3}{*}{$\mathbf{p}$} \\
\hline & \multicolumn{2}{|c|}{ Poor } & \multicolumn{2}{|c|}{ Good } & & & & \\
\hline & $\mathbf{n}$ & $\%$ & $\mathbf{n}$ & $\%$ & $\mathbf{N}$ & $\%$ & & \\
\hline \multicolumn{9}{|l|}{ Health Status } \\
\hline Poor & 33 & 94.30 & 2 & 5.70 & 35 & 100 & \multirow[t]{2}{*}{8.44} & \multirow[t]{2}{*}{0.002} \\
\hline Good & 43 & 66.20 & 22 & 94.30 & 65 & 100 & & \\
\hline \multicolumn{9}{|c|}{ Level of Independence } \\
\hline Not Independent & 41 & 89.10 & 5 & 10.90 & 46 & 46 & \multirow[t]{3}{*}{4.45} & \multirow[t]{2}{*}{0.005} \\
\hline Independent & 35 & 64.80 & 19 & 35.20 & 54 & 54 & & \\
\hline \multicolumn{8}{|c|}{ Intellectual Function } & \\
\hline Decrease & 23 & 95.80 & 1 & 4.20 & 24 & 24 & \multirow[t]{3}{*}{9.98} & \multirow[t]{2}{*}{0.009} \\
\hline Stable & 53 & 69.70 & 23 & 30.30 & 76 & 76 & & \\
\hline \multicolumn{8}{|l|}{ Depression Status } & \\
\hline Depressed & 53 & 85.50 & 9 & 14.50 & 62 & 62 & \multirow[t]{3}{*}{3.84} & \multirow[t]{3}{*}{0.005} \\
\hline Not Depressed & 23 & 60.50 & 15 & 39.50 & 38 & 38 & & \\
\hline \multicolumn{7}{|l|}{ Social Activities } & & \\
\hline Not Participating & 31 & 93.9 & 2 & 6.10 & 33 & 33 & \multirow[t]{2}{*}{$7 \cdot 57$} & \multirow[t]{2}{*}{0.003} \\
\hline Participating & 45 & 67.20 & 22 & 32.80 & 67 & 67 & & \\
\hline
\end{tabular}

$\mathrm{p}=0.002)$, independent $(\mathrm{OR}=4.45 ; \mathrm{p}=$ 0.005), good intellectual function ( $\mathrm{OR}=$ 9.98; $\mathrm{p}=0.009)$, not depressed $(\mathrm{OR}=3.84$; $\mathrm{p}=0.005)$, and actively participated in social activities ( $\mathrm{OR}=7.57 ; \mathrm{p}=0.003)$, were more likely to have good health status. The result was statistically significant. 


\section{Multivariate Analysis}

The results of multiple regression analysis test in analyzing the effect of health status, level of independence, intellectual function, depression status, and social activity on the elderly quality of life can be seen in Table 4 .

The score of Odds Ratio of health status variable was 11.66, which mean that there was a relationship between health status and the quality of life among elderly which was statistically significant. Elderly who have good health status were 11.66 times more likely to have good quality of life compared to those who have poor health status $(\mathrm{OR}=11.66 ; 95 \% \mathrm{CI}=2.18$ to 62.14 ; $\mathrm{p}=0.004)$.

The score of Odds Ratio of independence level variable was 4.12 , which mean that there was a relationship between level of independence and the quality of life among elderly which was statistically significant. Independent elderly were 4.12 times more likely to have good quality of life compared to those who were not independent $(\mathrm{OR}=4.12 ; 95 \% \mathrm{CI}=1.08$ to $15.60 ; \mathrm{p}=$ o.037).

The score of Odds Ratio of intellectual function variable was 9.75, which mean that there was a relationship between intellectual function and the quality of life among elderly which was statistically significant. Elderly who have good intellectual function were 9.75 times more likely to have good quality of life compared to those with decreased intellectual function $(\mathrm{OR}=9.75$; $95 \% \mathrm{CI}=1.09$ to $87.08 ; \mathrm{p}=0.036)$.

Table 4. The Results of Multiple Logistic Regression Analysis about Biopsychosocial Determinant of Elderly Quality of Life at Tresna Werdha Social Nursing Home, Yogyakarta

\begin{tabular}{lcccc}
\hline \multirow{2}{*}{ Variables } & \multirow{2}{*}{ OR } & \multicolumn{2}{c}{ 95\% CI } & \multirow{2}{*}{ p } \\
\cline { 3 - 4 } & & Lower Limit & Upper Limit & \\
\hline Health Status (good) & 11.66 & 2.18 & 62.14 & 0.004 \\
Level of Independence & 4.12 & 1.08 & 15.60 & 0.037 \\
(independent) & & & & \\
Intellectual Function (stable) & 9.75 & 1.09 & 87.08 & 0.041 \\
Depression Status (not depressed) & 3.38 & 1.01 & 11.24 & 0.047 \\
Social Activities (participating) & 6.02 & 1.12 & 32.25 & 0.036 \\
n observation = 100 & -2 log likelihood =69.26 & & \\
Nagelkerke R Square =50.30\% & \multicolumn{3}{c}{} \\
\hline
\end{tabular}

The score of Odds Ratio of depression status variable was 3.38 , which mean that there was a relationship between depression status and the quality of life among elderly which was statistically significant. Elderly who did not have depression were 3.38 times more likely to have good quality of life compared to those who have depression $(\mathrm{OR}=3.38 ; 95 \% \mathrm{CI}=1.01$ to $11.24 ; \mathrm{p}=$ 0.047).

The score of Odds Ratio of social activity variable was 6.02 , which mean that there was a relationship between social ac- tivity and the quality of life among elderly which was statistically significant. Elderly who participated in social activity were 6.02 times more likely to have good quality of life compared to those who did not participate in social activity $(\mathrm{OR}=6.02$; $\mathrm{CI} 95 \%=$ 1.12 to $32.25 ; \mathrm{p}=0.047)$.

The score of Nagelkerke R Square was 0.503, which mean that independent variable (health status, level of independence, intellectual function, depression status, and social activity) affected the dependent variable (quality of life) by $50.30 \%$, while 
Journal of Epidemiology and Public Health (2017), 2(1): 82-91

https://doi.org/10.26911/jepublichealth.2017.02.01.08

$49.70 \%$ were affected by other independent variables which were not examined in this study.

\section{DISCUSSION}

\section{The Effect of Health Status on the Quality of Life Among Elderly}

The result of this study showed that there was an effect of health status on the quality of life among elderly which was statistically significant. Elderly who have good health status were 11.66 times more likely to have good quality of life compared to those who have poor health status. This study was in line with a study done by Pereira, Nogueira, \& Silva (2015) entitled "Quality of Life and The Health Status of Elderly Persons: A Population-Based Study in The Central Sertao of Ceara", which involved the elderly who lived in Caninde, Ceara, Brazil. The result of this study showed that there was a relationship between health status and the quality of life among elderly in Caninde, Ceara, Brazil, especially in the psychological domain.

Health status was affected by several factors, namely environmental factors, behavioral factors, health service factors, and psychological genetic factors. Age was one of the biological environmental factors that could affect health status, the older the age of a person, the more vulnerable the health condition (Sulaeman, 2016).

The biological process of aging was a physical change that lead to a decrease in the efficiency of the body's organ system which caused several changes, one of them was a decrease in health status (Molton \& Jensen, 2010). This was important to be understood by the elderly, because elderly were more susceptible to a decline in health status, which would then have an impact on the their quality of life. Early awareness of this condition could help the elderly to minimize the decline in health status, minimi- ze the need for health services, and improve their quality of life (Lima \& Portela, 2010).

2. The Effect of Independence Level on the Quality of Life Among Elderly

The result of this study showed that there was an effect of independence level on the quality of life among elderly which was statistically significant. Independent elderly were 4.12 times more likely to have good quality of life compared to those who were not independent. This study was in line with a study done by Hongthong, Somrongthong, and Ward (2015) entitled "Factors Influencing the Quality of Life (QoL) Among Thai Older People in a Rural Area of Thailand", which involved the elderly who lived in Phayao, Thailand. The result of this study showed that there was an effect of level of independence, income, alcohol drinking habits, and illness on the quality of life among elderly in Phayao, Thailand.

The level of independence was a person's ability to perform daily activities related to physical function, such as showering, dressing, moving, defecating/urinating, and eating. As people get older, their ability to perform daily activities would also be decreased (Jabin, 2013).

The level of independence was one of the predictive factors on elderly quality of life, the dependence on daily activities became a statistically significant factor that affected the quality of life among elderly (Somrongthong et al., 2013).

\section{The Effect of Intellectual Function on the Quality of Life Among Elderly}

The result of this study showed that there was an effect of intellectual function on the quality of life among elderly which was statistically significant. Elderly who have good intellectual function were 9.75 times more likely to have good quality of life compared to those with decreased intellectual function. This study was in line with a study done by Syurandari (2014) entitled "Analysis 
of the Quality of Life Among Elderly in Mojokerto", which involved the elderly who lived in Mojopahit Nursing Home, Mojokerto and also in Kedungmaling, Sooko, Mojokerto. The result of analysis showed that age, gender, level of independence, marital status, education, life status, physical health (blood pressure, blood sugar, and BMI (Body Mass Index)), mental abilities, functional abilities, emotional abilities, intellectual function, healthy behavior, and family support have a significant effect on the quality of life among elderly, both who lived in Mojopahit Nursing Home, Mojokerto, and in Kedungmaling, Sooko, Mojokerto.

Intellectual function was the assessment of orientation, knowledge, short-term memory, long-term memory, and basic mathematical skills. The process of aging psychologically was a change in mental status, which could lead to a decline in intellectual function. The decline in intellectual function could be in the form of difficulty in remembering and reduced ability to make decisions, this was closely related to the quality of life among elderly, because the decline in intellectual function would have an implication in fulfilling the basic daily needs of the elderly (Maryam et al., 2008).

\section{The Effect of Depression Status on the Quality of Life Among Elderly}

The result of this study showed that there was an effect of depression status on the quality of life among elderly which was statistically significant. Elderly who did not have depression were 3.38 times more likely to have good quality of life compared to those who have depression. This study was in line with a study done by Kaur, M, Kaur, S, dan Kaur, R (2016) entitiled "Correlation of Depression and Quality of Life Among Rural Elderly", which involved the elderly who lived in Chhapa Ram Singh, Amritsar, Punjab, India. The result of this study sho- wed that there was a relationship between depression and the quality of life among elderly in Chhapa Ram Singh, Amritsar, Punjab, India, especially in the domain of environmental welfare.

Depression status was a condition of prolonged disturbance of mood which generally arised due to loss of hope or feelings of helpless. Psychological aging process was a change in mental status, which lead to depression. Depression in the elderly can also be caused by feelings of loneliness due to being abandoned by family members, this condition was often found in the elderly who lived in nursing homes, therefore, the elderly people were often locked up themselves, overthink about their fate, and refused to participate in various activities, which eventually lead to poor quality of life (Mehue, Rantetampang, \& Sandjaja, 2016).

\section{The Effect of Social Activity on the Quality of Life Among Elderly}

The result of this study showed that there was an effect of social activity on the quality of life among elderly which was statistically significant. Elderly who participated in social activity were 6.02 times more likely to have good quality of life compared to those who did not participate in social activity.

This study was in line with a study done by Supraba (2015) about "The Relationship between Social Activity, Social Interaction, and Family Function with Elderly Quality of Life in Community Health Center I of North Denpasar, Denpasar City”, which involved the elderly who lived in the working area of Community Health Center I in North Denpasar, Denpasar City. The result of the study showed that there was a relationship between social activity, social interaction, and family function with the quality of life among the elderly, and family function was the most dominant factor in affecting elderly quality of life in the working 
Journal of Epidemiology and Public Health (2017), 2(1): 82-91

https://doi.org/10.26911/jepublichealth.2017.02.01.08

area of Community Health Center I in North Denpasar, Denpasar City.

Activity theory stated that elderly who were always active and participated in many social activities were a successful elderly. Social activities in the elderly could reduce anxiety because elderly people could share with the others through the activities which were done together in community life, therefore, the availability of social activities in their lives could improve their quality of life (Yuli, 2014).

Based on the result of the study about biopsychosocial determinant of elderly quality of life at Tresna Werdha Social Nursing Home, Yogyakarta, it can be concluded that biopsychosocial determinants of the quality of life among elderly were health status, level of independence, intellectual function, depression status, and social activities.

\section{REFERENCE}

Central Statitical Agency (2011). Statistik Penduduk Lanjut Usia Provinsi DI Yogyakarta 2010: Hasil Sensus Penduduk 2010. Retrivied from https:// www.BPS.go.id/website/pdf_publikasi/Statistik-Penduduk-Lanjut-UsiaProvinsi-DI-Yogyakarta-2010.pdf 19 December 2016.

Central Statitical Agency (2016). Statistik Penduduk Lanjut Usia 2015. Retrieved from https://www.BPS.go.id/website/pdf_publikasi/Statistik-Penduduk-Lanjut-Usia-2015--.pdf 19 December 2016.

Central Statitical Agency Provinsi DI Yogyakarta (2016). Indikator Kesejahteraan Rakyat Daerah Istimewa Yogyakarta 2015. retrivied from http:// yogyakarta.BPS.go.id/website/pdf publikasi/Indikator-KesejahteraanRakyat-Daerah-Istimewa-Yogyakarta2015.pdf 19 Desember 2016.
Hongthong D, Somrongthong R, Ward P (2015). Factors influencing the quality of life (QoL) among Thai older people in a rural area of Thailand. Iranian Journal of Public Health. 44(4): 479485.

Jabin D (2013). The biopsychosocialogical components of natural aging and disease related aging.

Kaur M, Kaur S, Kaur R (2016). Correlation of depression and quality of life among rural elderly. International Journal of Advances in Nursing Management 4(4): 323-326.

Lima MJB, Portela MC (2010). Development and reliability evaluation of an instrument to measures healthrelated quality of life in independent elderly. Cadernos de Saude Publica, 26(8): 1651-1662.

Maryam S, Ekasari MF, Rosidawati, Jubaedi A, Batubara I (2008). Mengenal Usia Lanjut dan Perawatannya. Jakarta: Salemba Medika.

Mehue D, Rantetampang AL, Sandjaja B (2016). Factors affecting depression to old age at rehability old age and home family registered health primary Sentani, Jayapura Regency, Papua Province. International Journal of Sciences: Basic and Applied Study 30(5) 263-279.

Ministry of Health (2016). Situasi Lanjut Usia (Lansia) di Indonesia. retrivied from http://www.depkes.go.id/resources/download/pusdatin/infodatin/i nfodatin\%2olansia\%202016.pdf 19 December 2016.

Molton IR, Jensen, MP (2010). Aging and Disability: Biopsychosocial Perspectives. Physical Medicine and Rehabilitation Clinics of North America 21(2): 253-265.

Murti B (2016). Prinsip dan Metode Riset Epidemiologi. Surakarta: Program 
Studi Ilmu Kesehatan Masyarakat Program Pascasarjana Universitas Sebelas Maret.

Nugroho W (2008). Keperawatan Gerontik dan Geriatrik. Jakarta : EGC.

Pereira DS, Nogueira JAD., Silva CAB (2015). Quality of life and the health status of elderly persons: A population-based study in the Central Sertao of Ceara. Revista Brasileira de Geriatria e Gerontologia. 18(4): 893-908.

Somrongthong R, Wongchalee S, Yodmai K, Kuhirunyaratn P, Sihapark S, Mureed S (2017). Quality of life and health status among thai elderly after economic crisis, Khon Kaen Province, Thailand. European Journal of Scientific Study 112(3): 314-324.

Sulaeman ES (2016). Promosi Kesehatan: Teori dan Implementasi di Indonesia. Surakarta : UNS Press.

Sunaryo, Wijayanti R, Kuhu MM, Sumedi T, Widayanti ED, Sukrillah UA, Riyadi S, Kuswati A (2015). Asuhan keperawatan gerontik. Yogyakarta: Andi.

Supraba NP (2015). Hubungan aktivitas sosial, interaksi sosial, dan fungsi keluarga dengan kualitas hidup lanjut usia di wilayah kerja Puskesmas I Denpasar Utara Kota Denpasar. retrivied from http://www.pps.unud. ac. 4 January 2017.

Swarjana IK (2016). Keperawatan Kesehatan Komunitas. Yogyakarta : Andi.

Syurandari DH (2014). Analisis Kualitas Hidup Lansia di Kabupaten Mojokerto. retrivied from http://adln.lib. unair.ac. id/ files/disk1/737/gdlhubgdl-s3-2014-syurandari-36806-5.abstr-t. pdf 27 January 2017.

Tamher S, Noorkasiani (2009). Kesehatan Usia Lanjut dengan Pendekatan Asuhan Keperawatan. Jakarta: Salemba Medika.

UN (2015) World Population Prospects The 2015 Revision: Key Findings and Advance Tables. retrivied from https://esa.un.org/unpd/wpp/publications/files/key_findings_wpp_2015.pdf 19 Desember 2016.

UWO-HAMS (2007). Biopsychosocial Assessments in Aging. https:// instruct.uwo.ca/kinesiology/9641/index. html retrivied from27 Januari 2017.

Yuli R (2014). Buku Ajar Asuhan Keperawatan Gerontik. Jakarta: Trans Info Media 